\title{
Ritual Akkattere Sebag Ai Kepercayaan Masyarakat Di Desa Tana Towa Kecamatan Kajang Kabupaten Bulukumba
}

\author{
Nurilmi \\ Mahasiswa Pascasarjana S2 Sosiologi Universitas Hasanuddin
}

\begin{tabular}{l}
\hline \hline Article Info \\
\hline Article history: \\
Received 20 Desember 2021 \\
Publish 04 Januari 2022
\end{tabular}

Keywords:

Ritual

Akkattere

Community Trust

\begin{tabular}{l}
\hline Info Artikel \\
\hline Article history: \\
Diterima 20 Desember 2021 \\
Publis 04 Januari 2022
\end{tabular}

Publis 04 Januari 2022

\begin{abstract}
This study discusses the Akkattere ritual as a community belief in Tana Towa Village, Kajang District, Bulukumba Regency. The method used is a qualitative method. Data collection techniques used are Observation, Interview, and Dokumentation. In analyzin a data can be done by means pf data reduktion, data presentation, and drawing conclusions. It can be concluded that Akkattere is an activity in the form of a traditional party which includes hair cutting carried out by traditional stakeholders of the Tana Towa area. This ritual is a pair/message from their ancestors which is still being carried out. With the aim ofgetting a happiness in this worl and the here after. The implementation process also requires a very large cost. Akkattere also has no value if those who carry it out do dot have good behavior,

\begin{tabular}{l}
\hline ABSTRAK \\
Penelitian ini membahas tentang ritual Akkattere sebagai kepercayaan \\
masyarakat di Desa Tana Towa Kecamatan Kajang Kabupaten Bulukumba. \\
Metode yang digunakan adalah metode kualitatif. TehnikPengumpulan data \\
yang digunakan adalah Observasi, Wawancara, dan Doku mentasi. dalam \\
menganalisis suatu data dapat dilakukan dengan cara reduksi data, penyajian \\
data, serta penarikan kesimpulan. Dapat disimpulkan bahwa Akkattere adalah \\
sebuah kegiatan berupa pesta adat yang terdapat didalamnya pemotongan \\
rambut yang dilakukan oleh pemangku adat daerah Tana Towa. Ritual ini \\
merupakan Pasang/pesan dari leluhur mereka yang hingga saat ini masih \\
dilaksnakan. Dengan tujuan untuk mendapatkan suatu kebahagian dunia \\
maupun akhirat. Proses pelaksanaanya pun membutuhkan biaya yang sangat \\
besar. Akkattere juga tidak ada nilainya apabila yang melaksanakan tidak \\
memiliki prilaku yang baik.
\end{tabular}
\end{abstract}

This is an open access article under the Lisensi Creative Commons AtribusiBerbagiSerupa 4.0 Internasional

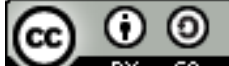

\section{Corresponding Author:}

\section{Nurilmi}

Mahasiswa Pascasarjana S2 Sosiologi Universitas Hasanuddin

Email : nurilmi097@gmail.com

\section{PENDAHULUAN}

Setiap daerah memiliki berbagai macam tradisi dan memiliki nilai-nilai lokal dan keunikan tersendiri, adapun keunikan tradisi yang menarik yaitu upacara adat. Upacara adat merupakan identitas budaya lokal dalam suatu masyarakat. Upacara adat sangat penting bagi masyarakat terhadap periode tertentu. Menurut Koentjaraningrat (1980 : 140) mengatakan bahwa upacara adat merupakan sebuah kegiatan yang dilakukan secara bersamaan terhadap suatu masyarakat atau komunitas sebagai bentuk kebangkitan dalam diri masyarakat. Beragam upacara adat misalnya upacara kematian, upacara perkawinan, dan upacara pengukuhan. Thomas Wiyasa, (2000:1) mengemukakan bahwa upacara adat merupakan sebuah kegiatan yang bersifat tradisional yang diselenggarakan secara turun-temurun yang memilki makna dan tujuan tertentu. Tradisi dapat dilahirkan oleh manusia merupakan adat istiadat, yaitu sebuah kebiasaan namun lebih ditekankan terhadap kebiasaan yang bersifat supranatural yang diliputi dengan nila-nilai budaya, norma-norma, hukum dan aturan yang berkaitan. Beserta tradisi yang ada dalam suatu masyarakat merupakan hasil untuk berperan penting sebagai individu, dalam 
suatu budaya terdapat nilai moral dan kepercayaan sebagai suatu penghormatan kepada yang menciptakan kebudayaan tersebut dan diaplikasikan dalam suatu komunitas mayarakat melalui tradisi.

Kebudayaan dapat dirumuskan sebagai hasil karya, rasa, cipta masyarakat. Masyarakat dapat menghasilkan tekhnologi dan kebudayaan yang diperlukan oleh manusia agar kekuatan serta hasilnya dapat diabadikan untuk keperluan masyarakat Soejono Soekanto (1990 : 198). Bangsa indonesia pada hakikatnya memilki kekayaan budaya yang heterogen karena masyarakat memilki multi etnis, agama, dan kepercayaan. Negara ini memilki keberagaman budaya yang tinggi. Keberagaman inilah merupakan identitas bangsa yang dipertahankan serta dipelihara karena memiliki keyakinan yang kuat terhadap tradisi yang berkembang disekirnya. Keyakinan inilah yang dimiliki oleh suatu komunitas yang memiliki upaya untuk mempertahankan serta melestarikan kebudayaan yang biasa disebut dengan Tradisi Lokal yang erat kaitannya dengan unsur agama dari luar.

Desa Tanah Towa, Kecamatan Kajang, Kabupaten Bulukumba merupakan kawasan adat dimana masyarakat dalam kawasan tersebut masih melestarikan yang diwariskan oleh nenek moyang mereka secara turun temurun sebagai bentuk penghargaan terhadap leluhur mereka. Warisan leluhur mereka berupa tradisi, adat-istiadat, dan kebiasaan. Tradisi lebih berorientasi terhadap kepercayaan dan ritual yang mengakar dalam masyarakat tersebut.

Ada beberapa tradisi dalam Tanah Towa yang diwariskan oleh leluhur mereka. Tradisi komunitas Kajang memiliki keunikan tersendiri yang dijadikan sebagai ciri khas dan perbedaan dari tradisi yang lainnya. Adat kajang dapat dibedakan dalam dua kelompok. Pertama Tanah kamase-masea (tanah yang sederhana) atau Ilalang Embayya (dalam batas) yaitu masyarakat yang tinggal di dalam kawasan adat atau disebut Kajang dalam. Kedua Tana Koasayya atau Ipantarang Embayya yaitu masyarakat yang tinggal diluar kawasan adat atau disebut Kajang luar.

Tradisi yang masih terjaga sampai saat ini adalah Akkatter yang dijadikan sebagai identitas masyarakat Tanah Towa. Tradisi Akkattere bagi masyarakat Kajang merupakan sesuatu yang sakral, ketika melakukan tradisi tersebut orang yang beruntung melakukan hajatan Akkattere akan mendapatkan pahalanya diakhirat nanti merupakan keyakinan masyarakat tersebut. Akan tetapi apabila orang tersebut menyombongkan diri dan melanggar larangan Tu Rie' A'ra'na maka tidak akan mendapatkan pahala Akkattere tersebut.

Dalam hal ini penelitian tentang ritual Akkattere sebagai kepercayaan di desa Tana Towa kecamatan Kajang Kabupaten Bulukumba masih sangat terbatas. Beberapa pengamatan peneliti tentang ritual Akkattere bahwa di dalam melaksanakan ritual tersebut masih berlangsung hingga saat ini, meskipun sebagaian masyarakatnya sudah berkembang. Oleh karena itu penelitian ini diangkat untuk mengungkapkan proses ritual Akkattere

\section{METODE PENELITIAN}

Penelitian ini menggunakan metode kualitatif, dimana metode kualiatatif adalah suatu aturan yang menghasilkan data deskriptif berupa data tertulis maupun secara lisan terhadap masyarakat (Djajasudarman, 2015), beserta didukung oleh metode wawancara etnografi dan Spredlay (Spradlay, 2007). Adapun kriteria-kriteria untuk menentukan informan yaitu tokoh budaya dan masyarakat yang melaksanakan ritual Akkattere. Pengumpulan data yang digunakan adalah Observasi, Wawancara, dan Dokmentasi. Analisis yang digunakan untuk data kualitatif mengacu pada model yang dikatakan oleh Miles dan Huberman bahwa kegiatan dalam menganalisis suatu data kualiatatif dapat dilakukan secara interaktif hinggan selesai. Kegiatan dalam menganalisis suatu data adalah: reduksi data, penyajian data, serta penarikan kesimpulan (Sugiyono :2016). Kesimpulan dapat ditentukan dengan divalidasin serta divalidasi dengan triangulasi data dengan informan dan ahli. 


\section{HASIL DAN PEMBAHASAN}

\subsection{Sejarah Ritual Akkattere}

Sejarah Akkattere yang biasa dilaksanakan oleh masyarakat Tana Towa tidak dijelaskan secara terperinci bagaimana sejarah Akkattere dari awal, akan tetapi masyarakat Tana Towa percaya terhadap Pasang ri kajang. Adapun pasang yang dikatakan terhadap Bohe Amma ri Kajang yaitu : punna nakku ko ri tanah lompoa tanah makka ri Kajang, lalang daerahna Ammatoapunna akrakko lampa hajji maka akkattereko. Akkattereko nampa nasabbiko ada' limayya na ada' tallu. Tapi punna tala nukelleangpi akkattere aklampako ri masigia. (Pasang ini diartikan sebagai apabila engkau merindukan Tanah Suci Mekah dalam daerahnya Ammatoa. Apabila ingin naik1 haji maka laksanakanlah Akkattere. Apabila engkau melaksanakan Akkattere engkau akan di saksikan oleh adat lima dan adat tallu. Dan apabila engkau belum bisa melaksanakan Akkattere maka ke mesjidlah).

Punna nukulleanggi a'boja doi, anggusaha pare, anggusaha tedong gaukanggi nu Akkatterea salama' naik haji. Sejarah Akakattere tidak sama dengan sejarah pada umumnya yang menjelaskan asal-usulnya. Orang yang pertama kali melaksanakan prosesi Akkattere adalah pada saat Bohe Amma Towa mengatakan Pasang tersebut, padasaat itulah masyarakat yang meyakini hal tersebut mulai melaksanakannya.

\subsection{Pelaksanaan Ritual Akkattere}

Persiapan untuk melaksanakan Akkattere dapat memakan waktu hingga 1 bulan lamanya. Dan prosesi Akkattere dapat dilaksanakan selama 1 minggu bahkan lebih. Proses Akkattere di Tanah Towa dapat dilihat dari hasil wawancara dengan saudari Rosmaningsih dimana prosesi Akkattere satu minggu sebelum acara hingga selesai.

Pertama masyarakat bekerja sama untuk membuat barung-barung atau penghubungNrumah untuk perosesi Akkattere. Masyarakat yang melakukan hal tersebut adalah laki-laki.

Kedua sampai hari ke-lima masyarakat pada umumnya seperti perempuan datang ke rumah yang akan melaksanakan acara tersebut dengan maksud membantu persiapan Akkattere. Misalnya, membuat kue merah, songkolo (dalam bentuk nasi yang terbuat dari beras ketan), serta mengatur perlengkapan yang lainnya.

Keenam dipagi hari diadakanlah ritual yaitu dibuatkan tempat rambut yang terbuat dari tempurung kelapa. Pada saat sore hari tiba maka dilaksanakanlah acara Akkattere tersebut dengan dimasukkan ke dalam tabere-bere (sebuah tempat duduk kecil yang terbuat dari anyaman bambun)tempat khusus tersebut, akan dipersiapkan pakaian yang akan digunakan yang akan disimpan dalam tepa' (bakul) yang didampingi oleh kerabat keluarga yang telah melaksanakan Akkattere. Orang yang akan dikattere menggunakan Sarung Hitam (tope le'leng) yang diluarnya menggunakan kain kafan dalam bentuk sarung untuk mandi di sumur rumah yang akan diKattere.

Setelah tiba di sumur tersebut dilurukan atau dipijat dengan menggunakan santan kelapa. Kemudian dimandikan oleh orang yang memiliki wewenan tersebut dan tidak menggunakan sabun. Adapun pakaian yang digunakan yaitu baju kai (pakaian adat kajang yang khusus digunakan oleh kaum perempuan) bagi perempuan dan baju sigara (pakaian adat kajang yang khusus digunakan oleh kaum laki-laki) Bagi laki-laki. Setelah prosesi dimandikan diperkenangkan untuk kembali kerumahnya tanpa mengerjakan apapun dan diperintahkan untuk memasuki tabare, pada saat malam hari akan diadakan proses panggadakkan di rumah yang melaksanakn ritual Akkattere tersebut.

Ketujuh dipagi hari yang melaksanakan akkattere melaksanakan yang dinamakan a'nini tedong (mengelilingi kerbau) sebulum kerbau tersebut disembelih, setelah a'nini tedong diarahkan untuk kembali kerumah. Untuk acara sore harinya kembali dimandikan dan menggunakan pakaian yang di tentukan dalam pelaksanaan Akkattere tersebut serta menunggu 26 adat. Pada saat 26 adat ini telah tiba, maka dihamburkanlah uang recehan dalam talenan serta orang yang akan di Kattere mengumpulkan uang tersebut kedalam mangkok. 26 galla diantaranya adalah Amma Towa, Galla Pantama, Galla Kajang, Galla 
Lombo, Galla Puto. Galla Malleleng, Pu' Kali' (Sara'), Moncong Buloa, Salehatan, Karaeng Kajang (Tu Labbiria), Galla Bantalang, Galla Sapa, Galla Ganta, Galla Anjuru, Lompo Ada', Panre, Tutoa Sangkala, Anrong Guru, Karaeng Pattongko, Loha Karaeng, Kadaha, Galla Jojjolo, Lompo karaeng. Sebelum memulai prosesi pemotongan rambut rambut, adapun prosesi selanjutnya yaitu: anggada' (berkumpulnya ke-26 adat terbut), kelong jaga (menyanyikan lagu yang khusu untuk acara pesta, angginung/minum (sesuatu yang disugukan misalnya air, kopi dll), Abbua atau nihuai (prosesi pemotongan rambut).

Setelah pemiliki pesta mengahmpiri adat tersebut untuk pemotongan rambut. Yang akan di Kattere duduk kemudian di tutup menggunakan sarung yang telah digunakan serta memegang ohang yang bentuknya seperi perak berwarna perak. Kemudian satu persatu pemangku adat memasuki tabare, duduk dihadapn yang akan diKattere serta melaksanakan prosesi selanjutnya hingga pemotongan rambut dilaksanakan dengan menggunakan besi perempuan yang berbentuk parang kecil dan alat yang digunakan untuk laki-laki adalah Badik Tua. Apabila ada salah satu galla (pemangku adat) tidak hadir maka pelaksanaan Akkattere dibatalkan. Setelah pemotongan rambut selesai, maka diadakan a'dedde songkolo (menyiapkan songkolo "semacam nasi yang terbuat dari beras ketan") diatas piring berbentuk gunung kurang lebih $20-25 \mathrm{~cm}$. Kegiatan ini dilakukan oleh para perempuan, dedde yang telah dibentuk ditambahkan daging dan kue cucur atau kue merah yang dikenal dengan ciri khas Kajang yang dibungkus dengan daun pisang kemudian dilettakkan dihadapn pemangku adat masing-masing. Itulah beberapa prosesi Akkattere di Tana Towa sesui prosedur yang ditentukan.

\subsection{Nilai-Nilai Ritual Akkattere}

Nilai-nilai yang terdapat pada Akkattere, menurut hasil wawancara dengan pung Tabang bahwa Akkattere memiliki nilai yang sangat tinggi karena dilaksanakan kato silahi ( mensucikan diri dari hal-hal yang tidak baik dengan adanya penjanjian adat) dilaksanakan dengan kepercayaan terhadap Tu Tiek Akrana yang merupakan konsep ketuhanan dalam ajaran Pasang "Tu Rie Akrana" merupakan satu-satunya kekuasaan yang maha mutlat beserta merupan sumber dari semua sumber.

Menurut pung Mappa kepercayaan masyarakat bahwa yang telah melaksanakan Akkattere tidak diperkenangkan melaksanakan ibadah Haji ataupun Umroh di mekkah, apabila telah melaksanakan Akkattere kemudian ke mekkah untuk melaksanakan ibadah haji ada dua kemungkinan yang akan dialami oleh orang tersebut yaitu sakit-sakitan hingga mengalami kematian. Ritual Akkattere nampaknya sangat berpengaruh terhadap kehidupan masyarakat di Tanah Towa. Demikianlah masing-masing hasil wawancara penulis terhadap masyarakat Tanah Towa akan tetapi berbicara tentang kematian menurut peneliti secara pribadi kematian merupakan kehendak Allah SWT.

\section{KESIMPULAN}

Dapat disimpulkan dari penjelasan diatas bahwa Akkattere adalah sebuah kegiatan berupa pesta adat yang terdapat didalamnya pemotongan rambut yang dilakukan oleh pemangku adat daerah Tana Towa. Ritual ini merupakan Pasang/pesan dari leluhur mereka yang hingga saat ini masih dilaksnakan. Dengan tujuan untuk mendapatkan suatu kebahagian dunia maupun akhirat. Proses pelaksanaanya pun membutuhkan biaya yang sangat besar. Akkattere juga tidak ada nilainya apabila yang melaksanakan tidak memiliki prilaku yang baik.

\section{SARAN}

Sangat diharapkan oleh penulis bahwa semoga peneliti selanjutnya dapat melengkapi kekurangan penelitian ini terutama tentang Ritual Akkatere sebagai kepercayaan masyarakat di Tana Towa Kecamatan Kajang kaupaten Bulukumba. 


\section{UCAPAN TERIMA KASIH}

Terimakasih tak terhingga untuk semua pihak yang telah membantu penyelesaian artikel dengan judul Ritual Akkattere sebagai kepercayaan masyarakat di Tana Towa Kecamatan Kajang Kabupaten Bulukumba.

\section{DAFTAR PUSTAKA}

Akib Yusuf. 2008. Ammatoa Komunitas Berbaju Hitam. Makassar: Pustaka Refleksi

Brata widjaja, Thomas Wiyasa 2000. Perkawinan Adat Jawa. Jakarta : Pustaka Sinar Harapan Bungawati, 2017. Budaya Akkattere dan ImplikasinyaTerhadap Pengamalan Hukum Islam. UIN Alauddin Makassar

Herdiyanti, Jamilah Cholilah. 2017. Pergeseran Modal Sosial dalam Pelaksanaan Adat Mandi Belimau. Jurnal Society, Vol V, No 2.

Juma Darmapoetra. 2014. Kajang Pecinta Kebersamaan dan Pelestari Alam. Makassar: Arus Timur

Marhaeni Saleh, Ardianto 2019. Tradisi Akkatter. UIN Alauddin Makassar

Nismawati, Shermina, Andi Agustag, 2021. Eksistensi Tari Kebasaran Pada Masyarakat Minahasa. Universistas Negeri Makassar

Robi Darwis 2017. Tradisi Ngaruwat Bumi dalam Kehidupan Masyarakat. UIN Sunan Gunung Djati Bandung

Soejono Soekanto. 1990. Sosiologi Sebagai Suatu Pengantar. Jakarta: Rajawali Pers

Spradley, J.P 1979. The Ethnographic Interview. New York: Reinhart \& Winston

Spradley. 2007. Metode Etnografi. Yogyakarta: Tiara Wacana 